\title{
Financial Technology as a Tool of Digital Economy
}

\author{
G.V.Tcvetova*
}

\author{
Department of Economy and Financial Law, Far-Eastern Institute of Management - branch of "The Russian Academy \\ of Economic and Public Service by the President of the Russian Federation “, Khabarovsk, Russia \\ *Corresponding author. Email: mgalin1008@mail.ru
}

\begin{abstract}
The aim of the paper is to study financial technologies as a tool of digital economy and identify the factors that influence them. Approaches to study the definition 'financial technology' are systematized and the basic prerequisites conducive to their development in the world are determined. The factors influencing the development of financial technologies are analyzed. The risks that hinder advancement of financial technologies in the Russian Federation are identified; it is concluded that the development of financial technologies should be accompanied by a transformation in the field of education, providing training for specialists required in digital economy.
\end{abstract}

Keywords: digital economy, financial technologies, financial market, banks, digitalization

\section{INTRODUCTION}

Development of a state, combining economic, social, environmental efficiency and aimed at meeting current needs without compromising the future, is the basis for sustainable development. Financial technologies, which have been dynamically developing lately, are an instrument of sustainable development, since they allow not only to ensure the efficiency of the financial and credit sector, but also to ensure the availability of its services to society.

Financial technologies, providing access to various financial products and services, contribute to the development of the financial market, and are an integral part of digital economy. In addition to the obvious focus on improving the efficiency of financial systems, financial technologies are a tool to increase operational transparency and efficiency.

Improving operational efficiency is facilitated by a safe, unbiased understanding of the goods production conditions, which helps to stimulate the disclosure of information to customers at all levels of the technological chain.

A favorable environmental impact of financial technology is associated with the use of various online services and solutions aimed at the rational use of natural resources, as a result of which, for example, the paperwork is significantly reduced.

Thus, the aim of the paper is to study financial technologies as a tool of digital economy and to identify the factors that influence them.

\section{METHODS}

The study was carried out using a systematic approach by summarizing and systematizing theoretical ideas about the development of financial technologies presented in the works of Maslennikov V.V., Pertseva S.Yu., Katyayani J. and Varalakshmi C., Iman N., Haberly D., and MacDonald- Korth D.

The analysis of statistical data was carried out using materials of Deloitte Research Center, Go Mobile, PWC, reviews of Economic Commission for Europe, studies of McKinsey international company.

\section{DISCUSSIONS}

In domestic and foreign literature, various approaches to the definition of the term 'financial technology' are used. Foreign sources view financial technologies:

- as digital financial instruments, for example, Internet banking, electronic wallets, blockchain technology [1];

- as technologies and platforms that make services and products in the financial sector more accessible and more efficient [2].

When describing financial technologies, domestic authors emphasize their infrastructural component, emphasizing their belonging to a certain segment of the financial market. Thus, according to S.Yu. Pertseva, financial technologies represent a dynamically developing segment at the intersection of financial services and technology sectors [3]. V.V. Maslennikov refers to financial technology a combination of startups, technology companies, financial institutions and infrastructure players [4] Thus, the variety of approaches to the definition of 'financial technology' can be explained, on the one hand, by its absence in regulatory legal acts, and, on the other hand, by the presence of various prerequisites for the advancement of digital financial solutions.

The main prerequisites for the development of financial technologies in the world are:

- the desire of banks to establish partnerships with technology companies [5];

- the loss by banks of a monopoly on the provision of traditional (payment and other) services, as well as 
strengthening of the role of non-financial organizations in the financial market [6];

- popularity of remote customer service channels, which is associated with a high degree of their inclusiveness;

- increasing consumer demands for speed, quality and personalization of financial services;

In Russia, on average, $20 \%$ of retail bank customers prefer to use bank services through a mobile application. Для крупнейших банков их доля доходит до $30 \%$. The average number of active users in banking applications equals 250 thousand per month for iOS and 600 thousand for Android. [7]

Stimulation of the development of financial technologies is facilitated by the growing demand for them, state support provided in various forms, as well as emergence of new types of digital products and services. These same factors can also hamper the development of financial technology.

An increase in demand for financial services is explained by the increase in their accessibility for the population and organizations both in terms of coverage of remote territories, and possibility of providing citizens in need of special service conditions, as well as an increase in the efficiency of their provision. At the same time, the concern of citizens with the problem of personal data security can be considered a deterrent.

Social networking sites increase the level of interaction between clients, and they become more demanding and less loyal. It's easier for clients to make comparisons, they quicker move to competitors, which means that relationships with a client can turn out to be short-lived and mainly arise for a specific operation. Even now, with very little effort on the part of the client, one-click transfer of all funds is carried out, instructions for direct debiting are given, and a transition to a new provider is carried out. At the same time, demographic trends can also have serious consequences for traditional organizations of the financial services sector, since the youngest users are the least loyal clients [8].

The possibility of using financial technologies as the main tool to increase transparency of the economy explains its active support from the state. Financial technologies provide formation of an infrastructure, the presence of which is a prerequisite for the development of leading sectors of economy.

According to the study conducted by experts at Ernst \& Young, in 2016 the global volume of electronic payments amounted to about 9 trillion US dollars. Russia accounted for about $1 \%$ of the global market, while the annual growth of the Russian market is $20 \%$ with a global figure of $12 \%$. In 2016, the volume of the Russian market of innovative financial technologies in the segment of payments and transfers amounted to about 87 billion US dollars. This segment will continue to grow by an average of $31 \%$ per year and will reach 14.9 trillion US dollars by 2035. In Russia, the level of penetration of financial technologies into the segment of payments and transfers by 2035 will be equal to $96.3 \%$ [9].

According to Global Findex research conducted by the World Bank in 2017, 62\% of the world's adult population had an account with a financial institution. In Russia, the number of people with a commercial bank account exceeded the global average and amounted to $67 \%$ of the adult population [10].

It should be noted that about 2 billion people in the world do not have access to banking services. Therefore, the development of digital financial services, which are an alternative to expanding branch networks of credit organizations, helps to reduce bank costs and creates convenient channels for consumers to access financial services, regardless of their location.

The most demanded are financial technologies in the field of money transfers, payments and lending. These operations are especially demanded by the population of those countries where the availability of financial services is limited due to the lack of sufficient financial infrastructure, the creation of which requires considerable time and investment. The increasing availability of Internet resources every year contributes to the spread of mobile technologies that can provide quick and convenient user access to financial services.

The demand for financial technologies is also formed by those consumers of traditional banking services who are not satisfied with their quality, speed of delivery and cost. Thus, according to a survey of five thousand bank customers in six European countries conducted by Sopra Banking Software technology company, $78 \%$ of respondents consider it important to introduce innovations in banking services, $58 \%$ would like to go to a bank offering the most advanced technologies, and $46 \%$ are ready to use the services of non-traditional banks [11].

Consequently, consumers who are dissatisfied with the current level of traditional financial services, generate demand for digital financial services, encourage banks to invest in the development of financial technologies that meet the needs of customers, and to develop partnerships with developers of financial technologies.

The use of financial technologies allows us to expand the geographical coverage of users of financial services through the development of remote service channels, reduce the cost of financial services, and accelerate the launch of new financial products, as well as increase financial inclusion of handicapped groups, ensure transparency of cash flows, and increase the ability to inform, advise and support consumers.

A study conducted by specialists of Digital McKinsey global expert group confirms that as a result of start-tofinish digitalization of key processes in a traditional bank, the cost of services is reduced by $40-60 \%$ [5]. At the same time, bank customers receive benefits in the form reducing the time required to receive a service, and decreasing the number of documents issued. For banks, the advantages of digitalization include expansion of the clientele.

\section{CONCLUSIONS}

Despite the constraints, the Russian Federation as a whole is characterized by a high level of penetration of financial technologies. However, the financial technology market volatility is explained by the influence of various risks, 
[2].Iman, N. Traditional banks against fintech startups: A field investigation of a regional bank in Indonesia (2019) Banks and Bank Systems, 14 (3), pp. 20-33.

[3].Pertseva, S.Yu. Fintech: functioning mechanism/ S.Yu. Pertseva// Innovations in management. - 2017. No. 12. - pp. 50-53.

[4].Maslennikov, V.V. et al. New financial technologies are changing our world/ V.V. Maslennikov, M.A. Fedotova, A.N. Sorokin// Bulletin of the Financial University. - 2017. - Volume 21. - No. 2. - pp. 6-11.

[5].Digital Russia: New Reality [Electronic resource]: available at: https://www.mckinsey.com/ru/our-insights

[6].Main directions of financial technology development for the period of 2018-2020 [Electronic resource]: available

at https://www.cbr.ru/statichtml/file/36231/on_fintex_201 7.pdf

[7].Go Mobile released 2019 Mobile Banking Study [Electronic resource]: available at : https://adindex.ru/news/releases/2019/09/12/275432.pht $\mathrm{ml}$

[8].Technology of financial services in 2020 and beyond: revolutionary changes [Electronic resource]: https://www.pwc.ru/ru/banking/publications/_FinTech2 020_Rus.pdf

[9].Focus on fintech: prospects for market development in Russia [Electronic resource]: available at: https://ru.investinrussia.com/data/files/sectors/EYfocus-on-fintech-russian-market.pdf

[10]. Global Findex Database 2017 [Electronic resource]: available at: https://globalfindex.worldbank.org/

[11]. Tcvetova, G.V. Trends in the financial technologies development during the economy digitalization, Advances in Economics, Business and Management Research, volume 105, 1st International Scientific and Practical Conference on Digital Economy,Nov (2019), pp.232-235. DOI: https://doi.org/10.2991/iscde-19.2019.44

[12]. Focus on fintech: prospects for market development in Russia [Electronic resource]: available at: https://ru.investinrussia.com/data/files/sectors/EYfocus-on-fintech-russian-market.pdf 